\title{
DETERMINANT OF BRAND LOYALTY WITH COMMITMENT AS A MEDIATION: STUDY IN WARDAH COSMETICS IN BANDA ACEH
}

\author{
Monalisa Darajarti, Abdul Rahman Lubis and Sorayanti Utami \\ Department of Management, UniversitasSyiah Kuala, 23111, Indonesia
}

http://doi.org/10.35409/IJBMER.2020.3148

\begin{abstract}
This study is to knowthe the effect of brand trust and customer satisfaction on brand loyalty with commitment as a mediating variable in Wardah Brand Cosmetics in Banda Aceh. The data is collected on the customers of Wardah brand cosmetics in Banda Aceh with atotal sample of 100 respondents taken by purposive sampling technique. This study used Partial Least Square - Path Modelling (PLS-PM) as the data analysis method. The result figures that from the descriptive statistical test provides the Wardah brand trust is very trustworthy, customer satisfaction is very satisfied, commitment is very strong, and brand loyalty is very loyal. While, for the verification test, it shows that brand trust effects brand loyalty significantly, brand satisfaction effects brand loyalty significantly, brand trust effects brand commitment significantly, brand satisfaction effects brand commitment significantly, brand commitment effects brand loyalty significantly, brand trust effects brand loyalty through brand commitment significantly, and brand trust effects brand loyalty through brand commitment significantly. These all findings contribute to the realm of science that can update the causality theories from the previous ones. The originality lies in the combination of the models from the previous, and uses PLS to produce a statistical analysis. The limitation resides in the amount of variables and with one object only. The findings is also can be as a reference for the practical persons especially Wardah managers to formulate the marketing strategy.
\end{abstract}

Keyword: Brand Trust, Customer Satisfaction, Commitment, and Brand Loyalty.

\section{INTRODUCTION}

According to data from the Indonesian Cosmetics Union, the development of the beauty industry in Indonesia is currently experiencing very rapid growth. According to data from the Ministry of Industry (2018) last year, the growth of the cosmetics industry grew by $6.35 \%$ and increase to $7.36 \%$ in the first quarter of 2018 . Throughout the year, the cosmetics industry was expected to grow by $7.33 \%$ and touched $7.64 \mathrm{~T}$ in 2019 where itwas targeted to grow by $9 \%$ this year. The entrepreneurs in the beauty industry, both domestic and overseas might see this value as a potential market in cosmetics companies.

Not only foreign sales, but domestic cosmetics sales have also increased, such as Wardah's cosmetic products in Indonesia. Wardah is one of the products of PT Paragon Technology, which is the top 10 largest cosmetics company in Indonesia. The company was founded by NurhayatiSubakat in 2003. 


\section{International Journal of Business Management and Economic Review}

Vol. 3, No. 01; 2020

ISSN: 2581-4664

Wardah's signature beauty is a decades-old commitment to always put quality in supporting women to look beautiful according to their respective characters. Wardah also has three principles, namely Pure and safe, Beauty expert, and Inspiring beauty.Wardah also has halal certificates for their products. Apart from been certified as halal, consumers also really want a quality product that suits their needs. This quality is what will be embedded in the minds of consumers where they will be committed to theseWardah products because they feel satisfied with the brand.

Appropriate satisfaction that can even exceed expectations will bring consumers to effective relationships that are more concerned with the relationship between brand and consumers, which prove that brand trust is one of the cores in building strong relationships between brands and consumers and it positively influences brand loyalty.

According to (Delgado-Ballester and Munuera-Alemán, 2005), brand trust is having a high expectation, or possibility that the brand will bring positive results to the consumers. Therefore, producers must gain the trust of consumers in order to create consumer commitment from the beginning to the end. the trust of consumers in a brand proves that the consumer has bought or consumed a product from the brand so that it is able to form and create a positive experience.

A trust that is obtained from a consumer of a brand will produce something that is beneficial and has potential as a goal to be achieved because the results of the development of a product from the company are very dependent on the trust of its customers.

This loyalty can be used as a reference for consumers in deciding to repurchase in the future, and then consumers will recommend to others about the positive things about the product or the brand used, as well as being loyal to the product or brand. According to (Schiffman and Kanuk, 2009) brand loyalty is a consistent consumer preference for buying the same brand on a specific product or certain service category.

The brand gives importance to competition in the business world. There were many popular cosmetic products, but they are increasingly declining and even disappear from the market. The more variety of cosmetic products make the problems faced by cosmetic companies even more complicated.

Customer loyalty is not so easily achieved by the companies, PT Paragon Technology and Innovation is also no exception. It requires a long process to convince consumers that Wardah cosmetics products produced by PT Paragon Technology and Innovation are the best products. Specifically, in this condition customer loyalty to the customer towards the brand is a crucial concept. With very tight competition and low growth, the concept of brand loyalty is needed. Maintaining brand loyalty is more effective than the efforts to attract customers.

The brand loyalty is started by being aware of the existence of a brand, purchasing a product, using the product, and then evaluating it. If the product can meet the wishes and needs of the customers and satisfies them, then the product gets a positive value from the customers.In turn it raises the commitment of customer loyalty to the brand, and the purchase of the next product does not need much consideration anymore.

Wardah has different advantages from other cosmetics. Wardah brand cosmetics emphasizes itself as halal products. This "halalness"won the attention of the Muslim female segment. This benchmark in choosing halal certified cosmetics both the use of materials and the way of production is one of the considerations among Muslim women. Cosmetics that are 


\section{International Journal of Business Management and Economic Review}

Vol. 3, No. 01; 2020

ISSN: 2581-4664

labeled "halal" are not necessarily intended explicitly for veiled Muslim women only. Any woman who wants to look attractive, but not excessive can also choose this Wardah cosmetics.

\section{LITERATURE REVIEW}

\section{Brand}

Brand in marketing has an equally important role. As defined by The American Marketing Association in (Kotler and Keller, 2018), brand is defined as "A name, term, sign, symbol, or design, or a combination of them, intended to identify the goods or service of one seller or group of seller and to differentiate them from those of competitors. Therefore, the brand used can describe the characteristics of what products are presented by the seller to consumers. Brands are essential in identifying a product and not releasing the possibility that similar products are also evaluated by consumers differently depending on the characteristics of the product itself.

\section{Loyalty}

Brand loyalty is a measure of consumer loyalty to a brand(Rangkuti, 2002). Whereas (Schiffman and Kanuk, 2009)stated that brand loyalty is consistent consumer preference for making purchases of the same brand of specific products or certain service categories.

The level of customer loyalty also has several levels ranging from the lowest to the highest level (Aaker, 1991):

a. Switches, that is consumers who are not loyal at all. They are not interested in a product; any brand is considered adequate. They often switch product and sensitive to price changes.

b. Habitual buyers, that is consumers who are satisfied with a product, and they purchase it just due to a habit. They do not experience dissatisfaction with the product; However, they do not have a problem with switching to other products.

c. Satisfied buyers, that is, consumers who are satisfied with a brand, but they bear the cost of switching, costs of time, money or performance risks associated with the act of switching brands.

d. Likes the brand, that is, consumers who like a brand.

e. Commitment buyers, that is, loyal customers. They have the pleasure of finding or becoming customers of a brand.

Therefore, experts conclude that brand loyalty is a positive attitude and consumer preference in a brand where consumers choose to buy products with the same brand repeatedly.

According to (Sahin, Zehir and Kitapç1, 2011), brand loyalty is influenced by several factors including:

1. Brand Trust

If a consumer has believed in a brand, then that consumer can be said to have or often bought and consumed products from that brand, and the products from that brand can create and form a good and positive commitment to the brand.

2. Satisfaction

Satisfaction is an important step in forming loyalty but becomes less significant when loyalty starts to emerge through other mechanisms. Customer satisfaction is always the main cause of loyalty.

3. Commitment

Commitment is an emotional/ psychological relationship with a brand in a product 


\section{International Journal of Business Management and Economic Review}

Vol. 3, No. 01; 2020

ISSN: 2581-4664

group. If consumers have committed to a brand, so they will be loyal to the brand.
Trust

Trust is one of the main factors in establishing a relationship between sellers and buyers(Lien et al., 2015). The trust itself refers to positive beliefs about the dependence and reliability of an object or a person (Everard and Galletta, 2005). Trust arises when someone has confidence in the integrity and reliability (Kim and Kim, 2005) towards providers of products and services.

(Lau and Lee, 1999) state that there are five factors that can influence trust in a brand. These five factors are interconnected with entities that include the relationship between consumers and brands. The five factors are the company that created the brand, the brand itself, and the customer. Then (Lau and Lee, 1999) also position that trust in the brand or brand will produce brand loyalty. The relationship between the five factors with brand trust can be concluded as follows:

1. Brand characteristics have a vital role in determining consumers' decision making to trust a brand. Consumers assessthe brand before buying the products. Brand characteristics related to brand trust include predictability, reputation, and competence.

2. Company characteristics that are behind a brand can also affect the level of consumer confidence in the brand. Consumer knowledge about the company that is behind the brand of a product. These characteristics include a company's reputation, motivation, and integrity.

3. Consumer - Brand Characteristics are two groups that influence each other. Therefore, the characteristics of consumers - brands can influence trust in the brand. These characteristics include the similarity between emotional concepts and brand personality, brand preference, and brand commitment.

4. Satisfaction with a brand can be defined as the result of a subjective evaluation of what has been achieved by the selected brand in order to meet what is expected by consumers.

5. Brand Experience is the experience of consumers with these brands, especially in the scope of use. Thus, it can be concluded that consumer commitment to a brand is closely related to trust in the brand.

\section{Satisfaction}

Satisfaction is defined as affective response to a buying situation or positive affective reaction to the results from previous experience (Ganesan, 1994). Satisfaction is born from attitudes that are formed as part of previous experience (Ganesan, 1994), which then has an impact on subsequent purchases(Oliver, 1980).

Indicators of satisfaction variables, according to (Sahin, Zehir and Kitapçı, 2011) are:

a. Very satisfied with the brand service

b. Very satisfied with the brand of a product

c. Pleased with the brand of a product

d. Pleased with the services provided by employees of a product

e. This brand meets consumer needs

f. Satisfied with the right decision in brand selection

g. Tied to one brand

\section{Commitment}

Commitment can be defined as psychological feelings of the mind through attitudes regarding relationships with the company, and it will provide long-term benefits for both parties. 


\section{International Journal of Business Management and Economic Review}

Vol. 3, No. 01; 2020

ISSN: 2581-4664

Indicators of commitment variables, according to (Ou et al., 2014) are:

a. Feel proud to be able to maintain the product

b. Give the impression in the minds of consumers

c. Always in the minds of consumers

\section{Research Conceptual Framework}

The conceptual framework of this study is that customer loyalty is primarily determined by the presence of brand trust and customer satisfaction factors that are mediated by commitment. (Sahin, Zehir and Kitapç1, 2011) suggested that brand trust has a significant positive effect on brand loyalty.Research conducted by (Lin and Lee, 2012)suggests that brand trust has a direct positive effect on brand loyalty.

Satisfied consumers are consumers who have the potential to be loyal to the brand (Amalia, 2013). Affective commitment, expressing the free will of consumers to maintain their relationship with the brand based on their emotions about the brand, such as the feeling of ownership or respect, is used to represent customer intentions to support long-term relationships with consumers and brands.

Brand trust and commitment are the most important drivers of long-term brand-consumer relationships. Recent studies have shown that customer trust increases; consumers increasingly become committed to the brands they use (Philippe and N'Goala, 2009); (Thaichon, Lobo and Mitsis, 2012); (Veloutsou, 2015); (Sreejes and Roy, 2015).

Customers who are at the level of habitual buyers can be categorized as consumers who are satisfied with the brand of products used. Companies will achieve better brand performance if they can effectively transform brand trust into brand satisfaction and consumer commitment to obtain customer loyalty (Philippe and N'Goala, 2009). Based on the above relationship, the research paradigm and hypothesis of thisresearch is constructed as follows:

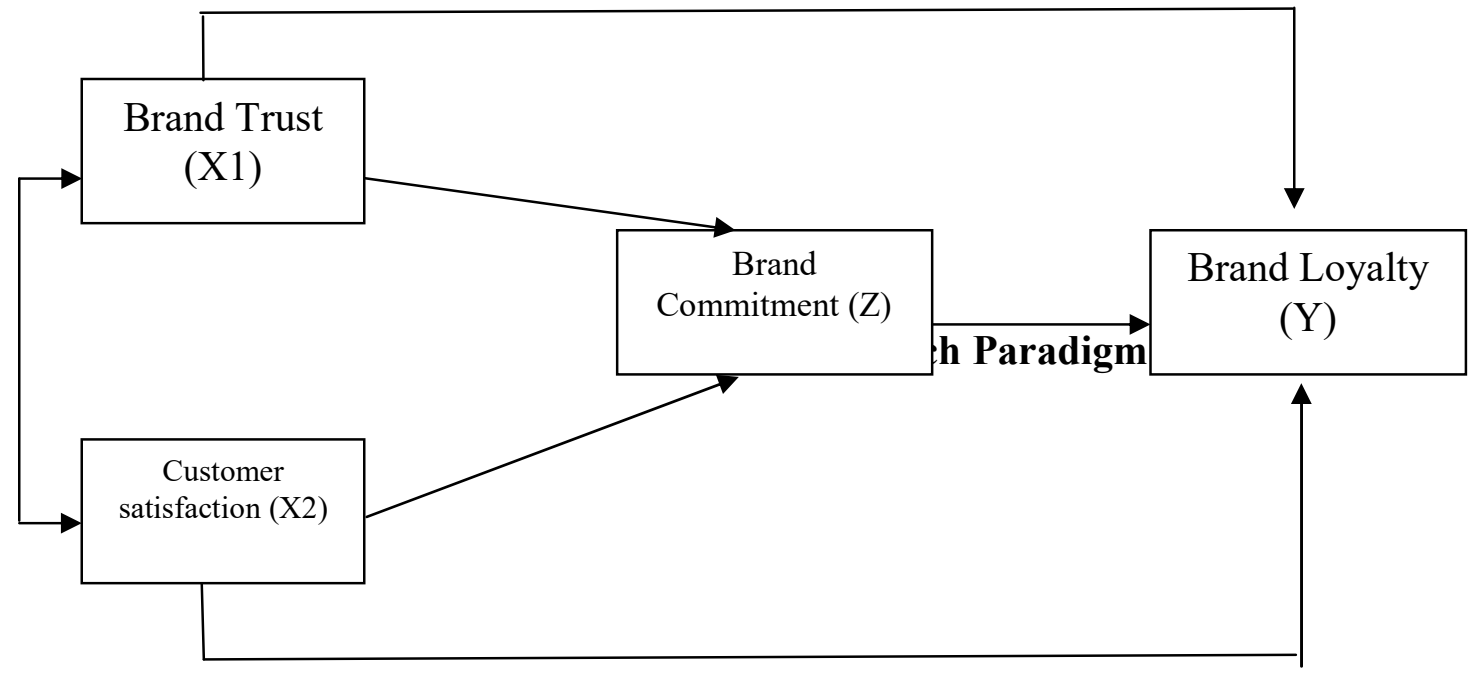

$\mathrm{H} 1$ : Brand trust effects brand loyalty significantly

$\mathrm{H} 2$ : Brand satisfaction effects brand loyalty significantly

$\mathrm{H} 3$ : Brand trust effects brand commitment significantly 


\section{International Journal of Business Management and Economic Review}

Vol. 3, No. 01; 2020

ISSN: 2581-4664

H4 : Brand satisfaction effects brand commitment significantly

$\mathrm{H} 5$ : Brand commitment effects brand loyalty significantly

H6 : Brand trust effects brand loyalty through brand commitment significantly

H7 : Brand trust effects brand loyalty through brand commitment significantly

\section{METHOD}

Sample

The sample size of 100 respondents is collected for the research. The sampling method used is purposive sampling.In this technique the researcher chooses a sample based on an assessment of some of the exact characteristics needed from the sample members (Zikmund et al., 2013). This technique allows researchers to determine the sample based on specific considerations, in which population elements are selected based on the research conducted (Malhotra, 2010). In this research, the sample is every Wardah customer registered as a member in the Banda Aceh region.

\section{Reliability, Validity, Descriptive Analysis and Hypothesis Verification Test}

Reliability means the level of reliability of the results of a measurement. Measurements that have high reliability is the measurements that can provide reliable results. Validity shows a measure of the validity of a target. So, it can be said that the higher the validity of a test instrument, the more precise the test instrument.

Descriptive statistics is used to analyze data based on the results obtained based on the answers of respondents to each indicator measuring a variable. This is as an addition hypothesis that can complete the verification hypothesis $(\mathrm{H} 1 \mathrm{until} \mathrm{H} 7)$. The descriptive hypothesis questions above were formulated and tested with the descriptive statistical test hypothesis as follows:

1. Hypothesis for X1 $\mathrm{H}_{0}: \mu_{1} \leq 4$ Brand trust is very distrustful $\mathrm{H}_{\mathrm{a}}: \mu_{1} \geq 4$ Brand trust is very trustworthy

2. Hypothesis for X2 $\mathrm{H}_{0}: \mu_{1} \leq 4$ Customer Satisfaction is very dissatisfied $\mathrm{H}_{\mathrm{a}}: \mu_{1} \geq 4$ Customer Satisfaction is dissatisfied

3. Hypothesis for $\mathrm{Z} \quad \mathrm{H}_{0}: \mu_{1} \leq 4$ Commitment is not very strong $\mathrm{H}_{\mathrm{a}}: \mu_{1} \geq 4$ Commitment is very strong

4. Hypothesis for $\mathrm{Y} \quad \mathrm{H}_{0}: \mu_{1} \leq 4$ Brand loyalty is very disloyal $\mathrm{H}_{\mathrm{a}}: \mu_{1} \geq 4$ Brand loyalty is very loyal

In addition to the analysis using descriptive statistics, to see the characteristics of the respondents, the research data will also be analyzed using the PLS-SEM analysis tool, where the test model of this model is structural equation.

\section{RESULT}




\section{International Journal of Business Management and Economic Review}

Vol. 3, No. 01; 2020

ISSN: 2581-4664

\section{Reliability Test Results}

\begin{tabular}{|c|c|c|c|}
\hline Variable & $\begin{array}{c}\text { Cronbach's } \\
\text { Alpha }\end{array}$ & $\begin{array}{c}\text { Composite } \\
\text { Reliability }\end{array}$ & $\begin{array}{c}\text { Variant of } \\
\text { AVE }\end{array}$ \\
\hline Brand Trust & 0.950 & 0.958 & 0.846 \\
\hline $\begin{array}{c}\text { Customer } \\
\text { satisfaction }\end{array}$ & 0.935 & 0.948 & 0.742 \\
\hline Commitment & 0.939 & 0.956 & 0.724 \\
\hline Brand Loyalty & 0.896 & 0.923 & 0.675 \\
\hline
\end{tabular}

Source: Output Smartpls 3. 2019

Based on the table above, it can be seen that composite reliability meets the requirements and AVE value also meets the requirements for all indicators in the block, as well as the value of Cronbach's alpha is in accordance with the criteria.Thus, all the questions used in this research variable can be said to be reliable because they have met the Cronbach's alpha standard credibility with an alpha value of more than 0.60 , composite reliability above 0.70 and AVE variant values above 0.50

2. Validity Test Results

\begin{tabular}{|c|c|c|c|c|}
\hline & L & KM & \multicolumn{1}{|c|}{ KP } & K \\
\hline KM1 & 0.714 & $\mathbf{0 . 8 5 0}$ & 0.763 & 0.761 \\
\hline KM2 & 0.734 & $\mathbf{0 . 8 8 8}$ & 0.775 & 0.747 \\
\hline KM3 & 0.744 & $\mathbf{0 . 8 8 3}$ & 0.801 & 0.762 \\
\hline KM4 & 0.722 & $\mathbf{0 . 8 4 6}$ & 0.791 & 0.735 \\
\hline KM5 & 0.676 & $\mathbf{0 . 8 8 7}$ & 0.799 & 0.700 \\
\hline KM6 & 0.707 & $\mathbf{0 . 8 3 1}$ & 0.814 & 0.683 \\
\hline KM7 & 0.718 & $\mathbf{0 . 8 3 2}$ & 0.747 & 0.746 \\
\hline KM8 & 0.793 & $\mathbf{0 . 7 3}$ & 0.824 & 0.758 \\
\hline KP1 & 0.832 & 0.875 & $\mathbf{0 . 9 0 6}$ & 0.814 \\
\hline KP2 & 0.579 & 0.605 & $\mathbf{0 . 6 9 0}$ & 0.505 \\
\hline KP3 & 0.716 & 0.825 & $\mathbf{0 . 9 0 2}$ & 0.696 \\
\hline KP4 & 0.618 & 0.628 & $\mathbf{0 . 7 9 3}$ & 0.515 \\
\hline KP5 & 0.802 & 0.836 & $\mathbf{0 . 8 5 7}$ & 0.787 \\
\hline KP6 & 0.825 & 0.891 & $\mathbf{0 . 9 1 9}$ & 0.807 \\
\hline KP7 & 0.756 & 0.733 & $\mathbf{0 . 8 6 6}$ & 0.686 \\
\hline Commitment1 & 0.865 & 0.818 & 0.799 & $\mathbf{0 . 9 3 2}$ \\
\hline Commitment2 & 0,845 & 0.782 & 0.773 & $\mathbf{0 . 9 3 1}$ \\
\hline Commitment3 & 0.778 & 0.753 & 0.708 & $\mathbf{0 . 9 0 1}$ \\
\hline Commitment4 & 0.762 & 0.792 & 0.740 & $\mathbf{0 . 9 1 6}$ \\
\hline LM1 & $\mathbf{0 . 8 4 8}$ & 0.761 & 0.818 & $\mathbf{0 . 7 6 9}$ \\
\hline LM2 & $\mathbf{0 . 4 7 7}$ & 0.359 & 0.434 & 0.297 \\
\hline
\end{tabular}




\section{International Journal of Business Management and Economic Review}

Vol. 3, No. 01; 2020

ISSN: 2581-4664

\begin{tabular}{|l|l|l|l|l|l|}
\hline \hline & LM3 & $\mathbf{0 . 9 0 9}$ & 0.762 & 0.745 & 0.845 \\
\cline { 2 - 6 } & LM4 & $\mathbf{0 . 9 0 4}$ & 0.795 & 0.797 & 0.820 \\
\cline { 2 - 6 } & LM5 & $\mathbf{0 . 7 8 1}$ & 0.588 & 0.588 & 0.660 \\
\cline { 2 - 6 } & LM6 & $\mathbf{0 . 9 2 2}$ & 0.779 & 0.821 & 0.817 \\
\hline
\end{tabular}

Source : Output Smartpls 3. 2019

The criteria in cross loading in the above table state that all indicators measured will be higher than the values compared to other constructs (Yamin and Kurniawan, 2011). The output on the data above shows the root of AVE for each reflective construct variable has met the criteria of discriminant validity because its value is higher than the correlation between its latent variables.

\section{Descriptive Test Analysis}

One-Sample Test

\begin{tabular}{|c|c|c|c|c|c|c|c|}
\hline & \multicolumn{7}{|c|}{ Test Value $=3.40$} \\
\hline & \multirow[t]{2}{*}{$\mathrm{t}$} & \multirow[t]{2}{*}{ Mean } & \multirow[t]{2}{*}{ df } & \multirow{2}{*}{$\begin{array}{l}\text { Sig. } \\
\text { (2- } \\
\text { tailed) }\end{array}$} & \multirow{2}{*}{$\begin{array}{c}\text { Mean } \\
\text { Difference }\end{array}$} & \multicolumn{2}{|c|}{$\begin{array}{c}95 \% \text { Confidence Interval of } \\
\text { the Difference }\end{array}$} \\
\hline & & & & & & Lower & Upper \\
\hline KM & 6.857 & 3.81 & 99 & .000 & .410 & .29 & .53 \\
\hline KP & 8.647 & 3.89 & 99 & .000 & .490 & .38 & .60 \\
\hline LM & 5.385 & 3.76 & 99 & .000 & .360 & .23 & .49 \\
\hline Commitment & 5.647 & 3.76 & 99 & .000 & .360 & .23 & .49 \\
\hline
\end{tabular}

Source: Output SPSS. 2019

Based on the summary above, it can be concluded that for descriptive test (additional hypothesis for $\mathrm{X} 1, \mathrm{X} 2, \mathrm{Z}$, and $\mathrm{Y}$ ), all $\mathrm{H}_{\mathrm{a}}$ is accepted, and $\mathrm{H}_{0}$ is rejected. It means that Wardah is a trusted brand, satisfying, with high brand commitment, and high brand loyalty.

\section{Hypothesis Verification Test Analysis}

\begin{tabular}{|c|c|c|c|c|c|}
\hline \multirow{2}{*}{$\begin{array}{l}\text { Testing } \\
\text { Model }\end{array}$} & \multirow{2}{*}{ Variable } & \multicolumn{2}{|c|}{ Commitment (Z) } & \multicolumn{2}{|c|}{$\begin{array}{l}\text { Brand Loyalty } \\
\text { (Y) }\end{array}$} \\
\hline & & $\begin{array}{c}\text { Coef. } \\
(\beta)\end{array}$ & P-value & $\begin{array}{l}\text { Coef. } \\
(\beta)\end{array}$ & P-value \\
\hline \multirow{3}{*}{ Model 1} & Trust $\left(\mathrm{X}_{1}\right)$ & & & 0.845 & $<0.01$ \\
\hline & Satisfaction $\left(\mathrm{X}_{2}\right)$ & & & & \\
\hline & Commitment (Z) & & & & \\
\hline \multirow{3}{*}{ Model 2} & Trust $\left(\mathrm{X}_{1}\right)$ & & & & \\
\hline & Satisfaction $\left(\mathrm{X}_{2}\right)$ & & & 0.872 & $<0.01$ \\
\hline & Commitment (Z) & & & & \\
\hline \multirow{2}{*}{ Model 3} & Trust $\left(\mathrm{X}_{1}\right)$ & 0.856 & $<0.01$ & 0.320 & $<0.01$ \\
\hline & Satisfaction $\left(\mathrm{X}_{2}\right)$ & & & & \\
\hline
\end{tabular}




\section{International Journal of Business Management and Economic Review}

Vol. 3, No. 01; 2020

ISSN: 2581-4664

\begin{tabular}{|c|c|c|c|c|c|}
\hline & Commitment (Z) & & & 0.612 & $<0.01$ \\
\hline \multirow{3}{*}{ Model 4} & Trust $\left(\mathrm{X}_{1}\right)$ & & & & \\
\hline & Satisfaction $\left(\mathrm{X}_{2}\right)$ & 0.823 & $<0.01$ & 0.440 & $<0.01$ \\
\hline & Commitment (Z) & & & 0.523 & $<0.01$ \\
\hline \multirow{3}{*}{ Model 5} & Trust $\left(\mathrm{X}_{1}\right)$ & 0.855 & 0.01 & 0.844 & 0.01 \\
\hline & Satisfaction $\left(\mathrm{X}_{2}\right)$ & 0.239 & 0.01 & 0.604 & 0.06 \\
\hline & Commitment (Z) & & & 0.540 & 0.01 \\
\hline
\end{tabular}

Source : Output Smartpls 3. 2019

Based on the results of the table above, in Model 1, brand trust as an exogenous variable directly affects brand loyalty or endogenous variables with a coefficient value of 0.845 and significant. Thus, $\mathrm{H} 1$ which states that Brand Trust effects Customer Loyalty is accepted and rejects $\mathrm{H}_{0} 1$.

Model 2, Customer Satisfaction Variable as an exogenous variable directly affects Brand Loyalty with a coefficient value of 0.872 and significant. Thus, $\mathrm{H} 2$, which states that Customer Satisfaction affects Brand Loyalty, is accepted, and $\mathrm{H}_{0} 2$ is rejected.

In Model 3, brand trust has a significant effect on commitment with a coefficient of 0.856 . While commitment also has a significant effect on brand loyalty with a coefficient of 0.612 , and brand trust continues to have a significant effect on brand loyalty even though the coefficient value drops from 0.845 to 0.320 but is still significant or acceptable. Thus, $\mathrm{H} 3$, which states that brand trust affects commitment, is accepted, and $\mathrm{H}_{0} 3$ is rejected.

In Model 4, the Customer Satisfaction Variable has a significant effect on commitment with a coefficient of 0.823 . While commitment also has a significant effect on brand loyalty with a coefficient of 0.523 . Moreover, the direct effect of customer satisfaction on Loyalty has a significant effect $(\mathrm{p}=0.01)$ even though the coefficient drops from 0.872 to 0.440 . Thus, $\mathrm{H} 4$, which states that customer satisfaction affects the commitment is accepted, and $\mathrm{H}_{0} 4$ is rejected.

In Model 5, brand trust has a significant effect on Brand Loyalty with a coefficient of 0.844 . Furthermore, brand trust also has a significant effect on commitment with a coefficient of 0.855 . Customer Satisfaction has a significant effect on commitment with a coefficient of 0.239 . Commitment also has a significant effect on Brand Loyalty with a coefficient value of 0.540 . Moreover, Customer Satisfaction has a significant effect on brand loyalty with a coefficient of 0.604 and $\mathrm{p}=0.01$. Thus, H5 which states that commitment affects Brand Loyalty, is accepted, and $\mathrm{H}_{0} 5$ is rejected.

Then H6, which states that Brand Trust has a significant effect on Brand Loyalty through Commitment is accepted, and $\mathrm{H}_{0} 6$ is rejected.

Meanwhile, H7, which states that customer satisfaction has a significant effect on brand loyalty through commitment,is accepted and $\mathrm{H}_{0} 7$ is rejected. The above results also show that when commitment is included in the model, the direct effect of customer satisfaction on brand loyalty becomes significant with a coefficient of 0.604 .

This concludes that the influence of brand trust and customer satisfaction on brand loyalty is indirect and fully mediated by commitment. This means that when consumers are satisfied with the product, they will be committed to the product. Then customer satisfaction has a positive effect on brand loyalty through commitment, and the correlation coefficient is much lower than the effect of brand trust on brand loyalty through commitment, each of 0.844 and 0.604 . This 


\section{International Journal of Business Management and Economic Review}

Vol. 3, No. 01; 2020

ISSN: 2581-4664

means that brand trust has a stronger influence on brand loyalty than customer satisfaction with brand loyalty. In addition, commitment directly influences brand loyalty with a coefficient of 0.540. This means that when customers entrust a brand and are satisfied with a brand, the customer will commit to the brand and increase brand loyalty.

\section{CONCLUSION}

From the descriptive statistical test we can seethe brand trust is very trustworthy, customer satisfaction is very satisfied, commitment is very strong, and brand loyalty is very loyal.For the verification test,it shows that brand trust effects brand loyalty significantly, brand satisfaction effects brand loyalty significantly, brand trust effects brand commitment significantly, brand satisfaction effects brand commitment significantly, brand commitment effects brand loyalty significantly, brand trust effects brand loyalty through brand commitment significantly, and brand trust effects brand loyalty through brand commitment significantly. These all findings contribute to the realm of science that can update the causality theories from the previous ones. This research model can be accounted for statistically and as the basis for future related research. The originality lies in the combination of the models from the previous, and uses PLS to produce a statistical analysis. The limitation resides in the amount of variables that are only four, and with one object only. The findings is also can be as a reference for the practical persons especially for Wardah managers to formulate the marketing strategy.

\section{REFERENCES}

Aaker, D. A. (1991) Managing Brand Equity. United States: Free Press.

Amalia, L. (2013) 'Analisis Hubungan Kepuasan dengan Loyalitas Konsumen terhadap Sepeda Motor Yamaha Vixion pada Bengkel Abadi Motor Kebon Jeruk Jakarta Barat', Jurnal Ekonomi, 4(2).

Delgado-Ballester, E. and Munuera-Alemán, J. L. (2005) 'Does brand trust matter to brand equity?', Journal of Product and Brand Management, 14(3), pp. 187-196. doi: $10.1108 / 10610420510601058$.

Everard, A. and Galletta, D. F. (2005) 'How Presentation Flaws Affect Perceived Site Quality, Trust, and Intention to Purchase from an Online Store', Journal of Management Information Systems2, 22(3), pp. 56-95. doi: https://doi.org/10.2753/MIS07421222220303.

Ganesan, S. (1994) 'Determinants of Long-Term Orientation in Buyer-Seller Relationships', Journal of Marketing1, 58(2), pp. 1-19. doi: DOI: 10.2307/1252265.

Kim, H. B. and Kim, W. G. (2005) 'The relationship between brand equity and firms' performance in luxury hotels and chain restaurants', Tourism Management, 26(4), pp. 549560. doi: 10.1016/j.tourman.2004.03.010.

Kotler, P. and Keller, K. L. (2018) Marketing Management, Global Edition. 15th editi. Harlow, United Kingdom: Pearson.

Lau, G. T. and Lee, S. H. (1999) 'Consumers' Trust in a Brand and the Link to Brand Loyalty', Journal of Market-Focused Management, 4(4), pp. 341-370.

Lien, C. H. et al. (2015) 'Online hotel booking: The effects of brand image, price, trust and value 


\section{International Journal of Business Management and Economic Review}

Vol. 3, No. 01; 2020

ISSN: 2581-4664

on purchase intentions', Asia Pacific Management Review. Elsevier Ltd, 20(4), pp. 210218. doi: 10.1016/j.apmrv.2015.03.005.

Lin, M.-Q. and Lee, B. C. Y. (2012) 'The Influence Of Website Environment On Brand Loyality: Brand Trust and Brand Affect as Mediators', International Journal of Electronic Business Management, 10(4), pp. 308-321.

Malhotra, N. K. (2010) Riset Pemasaran: Pendekatan Terapan. 4 Jilid 2. Jakarta: Index.

Oliver, R. L. (1980) 'A Cognitive Model of the Antecedents and Consequences of Satisfaction Decisions', Journal of Marketing Research, 17(4), pp. 460-469. doi: DOI: $10.2307 / 3150499$.

Ou, A. Y. et al. (2014) 'Humble Chief Executive Officers' Connections to Top Management Team Integration and Middle Managers' Responses', Administrative Science Quarterly, 59(1), pp. 34-72. doi: 10.1177/0001839213520131.

Philippe, A. and N'Goala, G. (2009) 'he differing and mediating roles of trust and relationship commitment in service relationship maintenance and development', Journal of the Academy of Marketing Science, 38(3), pp. 303-325. doi: DOI: 10.1007/s11747-009-0163$\mathrm{z}$.

Rangkuti, F. (2002) The Power of Brand: Teknik Mengelola Brand Equity dan Strategi Pengembangan Merek. Jakarta: Gramedia Pustaka Utama.

Sahin, A., Zehir, C. and Kitapçı, H. (2011) 'The Effects of Brand Experiences, Trust and Satisfaction on Building Brand Loyalty; An Empirical Research On Global Brands', in Procedia - Social and Behavioral Sciences. Amsterdam, Netherlands: Elsevier Ltd, pp. 1288-1301. doi: https://doi.org/10.1016/j.sbspro.2011.09.143.

Schiffman, L. and Kanuk, L. L. (2009) Consumer Behavior. 10th edn. United States: Prentice Hall.

Sreejes, S. and Roy, S. (2015) A New Consumer Brand Relationships Framework. In: Fetscherin M., Heilmann T. (eds) Consumer Brand Relationships. London: Palgrave Macmillan. doi: https://doi.org/10.1057/9781137427120_9.

Thaichon, P., Lobo, A. and Mitsis, A. (2012) 'nvestigating the Antecedents to Loyalty of Internet Service Providers in Thailand: Developing a Conceptual Model', in ANZMAC 2012 Conference. Australia: Adelaide.

Veloutsou, C. (2015) 'Brand evaluation, satisfaction and trust as predictors of brand loyalty: the mediator-moderator effect of brand relationships', Journal of Consumer Marketing, 32(6), pp. 405-421. doi: 10.1108/JCM-02-2014-0878.

Yamin, S. and Kurniawan, H. (2011) Generasi Baru Mengolah Data Penelitian dengan partial Least Square Path Modelin. Jakarta: Salemba Infotek.

Zikmund, W. G. et al. (2013) Business research methods. 9th ed. United States: South-Western College Pub. 